\title{
Promoting Speaking Proficiency in Broadcasting Through YouTube Project: Perceptions of Undergraduate Students
}

\author{
Sri Wahyuningsih ${ }^{1}$, Siti Malaiha Dewi ${ }^{2}$ \\ Institut Agama Islam Negeri Kudus, Jl. Conge Ngembalrejo Bae 51 Kudus ${ }^{1,2}$ \\ \{wahyuningsih@iainkudus.ac.id ${ }^{1}$,dewimalaiha@yahoo.com²\}
}

\begin{abstract}
This article mainly investigated the perceptions of undergraduate students from the Department of Islamic Broadcasting Communication at State Islamic Institute of Kudus to the use of YouTube as project-based learning to foster speaking proficiency in broadcasting. The study was conducted as qualitative research and data were collected through the administration of a 15item questionnaire to the students relating the perception of YouTube project in enhancing their speaking proficiency in broadcasting. The result revealed that majority of the students agreed that YouTube project can facilitate the use of English based on their positive attitudes towards its use and high percentages of the perceptions that it can foster speaking of the language. Furthermore, YouTube encourages them to be more confident when speaking English and also has the ability to support their appearance or performance when broadcasting. It is, therefore, important for lecturers to design English speaking skills integrated into course materials through the use of modern technology.
\end{abstract}

Keywords: Broadcasting, Speaking Proficiency, Undergraduate Students, YouTube Project

\section{INTRODUCTION}

The development of technology has led to the potentials in media particularly the broadcasting developments that are highly embedded in the social life. In conjunction with broadcasting area, English has become one of the meaningful elements in communication by which people are able to interact with others in the digital era. Further, it has a crucial role in defining the various forms of sound and visual news presented by some broadcasters. With regard to this, they are highly recommended to have a speaking proficiency in broadcasting. Along with broadcasting, the role of media cannot merely be neglected in delivering news and information. Regarding this, the media has functions as an instrument, a channel and a transitional agency which is used as a means of communication [1]. In accordance with the spoken language, speaking plays a crucial role in conveying messages and ideas which have certain and different features from the written language. In this matter, those differences could be clearly seen from the quality of voice, gestures, facial expressions, intonation, pronunciation, stress, rhythm and pausing. As a matter of fact, speaking English may be not easy for beginners particularly the undergraduate students from the Islamic Broadcasting Communication Department at State Islamic Institute of Kudus. Considering that speaking is 
a productive skill that is more complex than pronouncing words, the undergraduate students may have problems in speaking English. It is in conjunction with Gan asserting that some problems that may be encountered by students in speaking English include inadequate vocabularies, the complicated grammar or structure, inappropriate intonation and pronunciation, lack opportunities of speaking English in class and society, lack of language curriculum development and input poor environment outside the classroom [2].

In addition, there are other aspects needed in speaking skills. They are social and cultural rules which deal with the strategies of doing turn-taking, participants' roles, and circumstances. With regard to this, students are highly fostered to speak by creating an interactive linguistic environment. In an interactive linguistic environment, such as with the EFL classroom, the right amount and the right kind of verbal interaction must occur simultaneously for learning to take place [3]. Along with it, lecturers should consider the use of social media in teaching speaking in order to respond the development of technology and attract the interest of students in speaking English. The number of social media such as YouTube, Facebook, and YouTube has increasingly been used in teaching English. Further, online social media have played a crucial part for college students especially in language learning [4]. In other words, social media can be considered as effective tools in fostering social learning. [5]

A number of studies related to the use of social media particularly YouTube have been previously undertaken by some researchers. In fact, the interest of utilizing YouTube in the educational aspect has become crucial [6]. YouTube provides fun access to language and instruction from all over the world and offers students with the great chance to achieve the target language meaningfully [7]. In addition, YouTube offers visual imagery to explore the attention spent on a stimulus that leads to stronger keys for obtaining the stored information [8]. Furthermore, YouTube can be used as a valuable instructional resource and can enhance students' digital learning style [9]. In other words, YouTube can be a free teaching resource and offer the opportunity to experience technology that will give students with marketable skills for better future careers. In accordance with the use of YouTube, lecturers and students can utilize YouTube to upload and share something by which they can publish the projects into YouTube which demonstrates a topic and create a social and digital community [10]. In higher education, the use of YouTube is not something new and it has prevalence as the educational tool to arouse students' outcomes and best practices [11]. In the context of English as a second language, YouTube has been increasingly used by educators as an educational resource for everything including the "slice-of-life" you tubes which can be used to teach students [12]. Interestingly, YouTube can be used as a learning tool to encourage students in understanding materials and exploring the topics [13]. Different from the previous studies that utilize YouTube as a media in the classroom, this article mainly focuses on the perception of YouTube project to foster speaking proficiency among the undergraduate students of the Islamic Broadcasting Communication Department at the State Islamic Institute of Kudus considering their low speaking proficiency since they are not from the English Department.

\section{METHODOLOGY}

This study anchors in a qualitative research. Although the findings are in the form of frequencies (e.g., the number of perceptions among undergraduate students dealing with the YouTube project) and percentage, the final product is in the form of a descriptive analysis or interpretation. In conjunction with a qualitative research, it mainly seeks to probe deeply into 
the research setting to obtain in depth understanding about the way things are, why they are that way, and how the participants in the context perceive them [14]. In gathering data, a 15item self- assessment inventory is conducted to describe self-perceptions of undergraduate students dealing with the importance of the speaking proficiency and a project-based learning uploaded in YouTube in English. This study is conducted in the Islamic Broadcasting Communication Department, Faculty of $D a$ 'wah and Islamic communication at State Islamic Institute of Kudus, comprising of 20 students of the second semester.

\section{FINDINGS AND DISCUSSION}

This study explores the self-assessment inventory analysis by adopting the data analysis formula advocated by Nalliveettil and Alenazi in which they "added up the number of responses given for the scale Agree + the number of the responses given for the scale Strongly Agree = Total percentage" [15]. In addition, they adopt the same procedure for the statements - Disagree and Strongly Disagree except the third scale - undecided. However, the self-assessment inventory conducted in this study consists of five scales namely: Strongly Disagree, Disagree, Undecided, Agree and Strongly Agree.The analysis of this study also adopts the procedure proposed by Nalliveettil and Alenazi where those students who mark Disagree and Strongly Disagree are grouped under one category since pointing out a different perception when compared to the students who mark Agree and Strongly Agree are categorized to be agreeing with the self-assessment statements. Furthermore, the data of students who mark Undecided are presented in percentages. The graphs below give an overview of the individual percentages of each of the scales. For the sake of clear elaborations, a set of 15 items are grouped together in a graphic form:

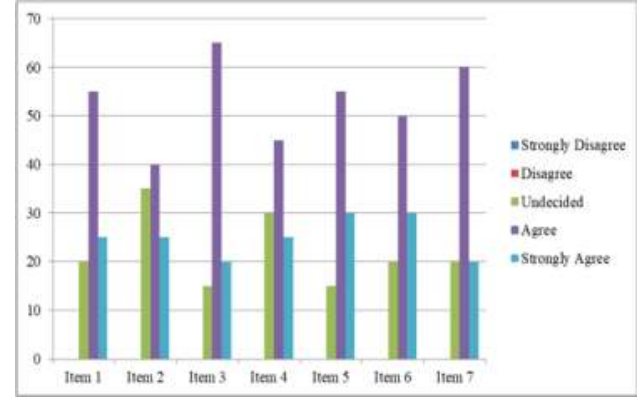

Graph 1: Analysis of Items 1 to 7

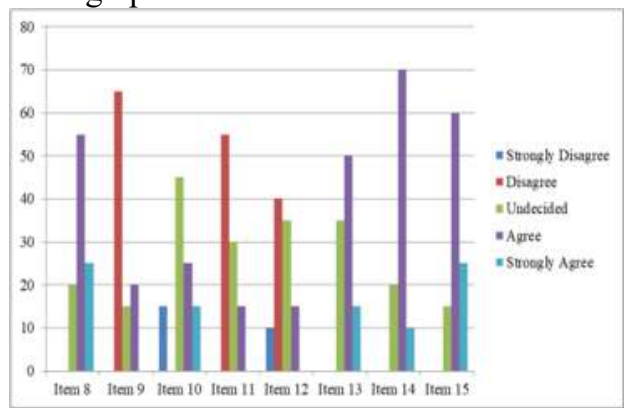

Graph 2: Analysis of Items 8 to 15

In order to give an overview of the undergraduate students' perceptions particularly in Islamic Broadcasting Communication Department regarding the use of YouTube as a projectbased learning in encouraging their speaking proficiency in broadcasting, the tables below are presented:

Table 1. List of Items 1 to 7

\begin{tabular}{cl}
\hline Item No. & \multicolumn{1}{c}{ Self-evaluation statements } \\
\hline 1 & By using YouTube, learning English becomes pleasurable and enjoyable \\
2 & By using YouTube, I become more confident when speaking English \\
3 & YouTube project can encourage me to speak English \\
4 & By using YouTube, I can practice English communication in broadcasting easily \\
5 & YouTube project can support me in broadcasting \\
6 & YouTube project can enhance my appearance when broadcasting \\
7 & I have positive attitude towards using YouTube \\
\hline
\end{tabular}


Table 2. List of Items 8 to 15

\begin{tabular}{cl}
\hline Item No. & \multicolumn{1}{c}{ Self-evaluation statements } \\
\hline 8 & YouTube project facilitates me in broadcasting using English \\
9 & It is difficult to make a YouTube as a project-based learning \\
10 & It takes time when making a project and uploading it in YouTube \\
11 & Learning English with leads to an unsocial setting of learning \\
12 & After some time, learning English with YouTube may turn out be boring \\
13 & I feel more comfortable while broadcasting using YouTube \\
14 & YouTube project provides a chance to redo \\
15 & YouTube project facilitates me in learning vocabulary \\
\hline
\end{tabular}

The percentages of each of the items above are described in graphic forms below:

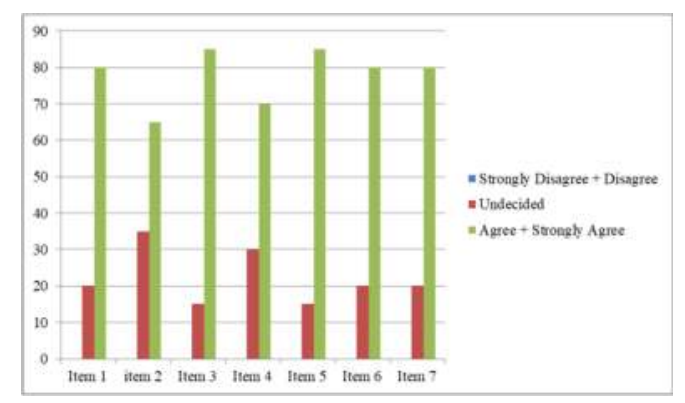

Graph 3. Analysis of Items 1 to 7

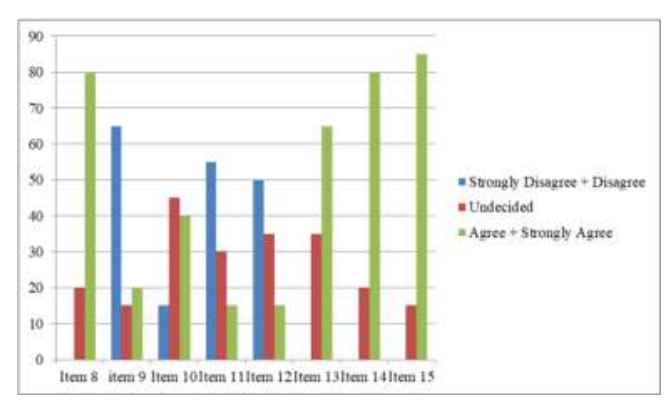

Graph 4. Analysis of Items 8 to 15

Based on Graph 3, it shows that the undergraduate students from the Islamic Broadcasting Communication Department of State Islamic Institute of Kudus mostly agree that YouTube could be an alternative way as a project-based learning to encourage their speaking proficiency and performance in broadcasting. They can merely enjoy learning English by making a project of English learning uploaded in YouTube. However, other students seem unsure that YouTube can foster a pleasurable learning which has been showed by their undecided or neutral responses. Then, the majority of undergraduate students are of the perceptions that YouTube project can make them more confident when they speak English. Indeed, they have to make well preparations before their project was uploaded in YouTube. Meanwhile, some students show their uncertain or neutral responses that YouTube can make them confident to speak English. Further, most students do agree that the YouTube project can encourage them to speak English while others show unsure responses, they do agree that they can easily practice broadcasting using English while others express their uncertain responses. Further, Graph 4 indicates that majority of undergraduate students from the Islamic Broadcasting Communication Department at State Islamic Institute of Kudus agree that YouTube facilitates them in broadcasting using English. As a matter of fact, before they are assigned to make a YouTube project of broadcasting using English, they seem nervous when speaking in English. Interestingly, after they are assigned to make a YouTube project of broadcasting using English, they become more confident to speak English in broadcasting.

In addition, some of them argue that making a YouTube project is easy while others show their uncertain or neutral responses and response of disagreement. In relation to making a YouTube project, most of the undergraduate students do agree that it takes time when 
making a YouTube while others disagree and show their unsure response. Furthermore, a higher percentage of these students seem disagree that learning English with YouTube leads to an unsocial setting of learning. Meanwhile, others show their unsure or neutral response and the agreement. The above graphs also indicate that a higher percentage of students seem disagree that after some time, learning English with a YouTube project could turn out be boring. On the contrary, they feel more enthusiastic when making a YouTube project of broadcasting using English. In addition, they can produce an innovative YouTube project. The analysis also indicates that a higher percentage of students feel more comfortable while broadcasting using English in YouTube. However, only few students show their uncertain responses. Indeed, the above graphs also show that the students mostly agree that YouTube provides a chance to redo and facilitates them in learning vocabulary. It means that when making a YouTube project, students will have much time to redo and they are surely demanded to learn more vocabularies when broadcasting using English in a YouTube.

From the above elaborations, it can be clearly deduced that social media including YouTube has been considered to be effective for learning. In this matter, students are able to increase their higher level thinking skills including decision making and problem solving, communicating and collaborating using social media [16]. On the other hand, YouTube can be considered as one of the instructions in learning English [17]. Along with the Perception of undergraduate Students towards the use of YouTube as a project- based learning to foster their speaking proficiency in broadcasting, most of the students in Islamic Broadcasting Communication Department of State Islamic Institute of Kudus have both positive and high perceptions towards the use of YouTube as a project-based learning in encouraging their speaking proficiency of broadcasting using English. The findings of this study coincide with the findings of Riasati reporting that students with higher perceptions of English speaking proficiency will increase their self-confidence and decrease the level of anxiety [18]. In other words, students with a high perception of communication will be more confident and willing to speak English. However, the influence of their mother tongues, Javanese, and the national language, Indonesian, may become the major factor that remains challenging.

Surprisingly, before being assigned to make a YouTube project of broadcasting using English, the students of Islamic Broadcasting Communication Department do not have any motivation to speak English though they will be a broadcaster in the future. Indeed, the assignment of making a YouTube project of broadcasting in English really motivates them to learn English vocabularies, enhances them to feel more confident when speaking English, engages them to be more creative and innovative in making a YouTube project, enhances them to explore their chance to redo and create improvisations. Furthermore, improvisation activities are badly needed for students in classroom practice especially in teaching English [19]. Referring to it, students will engage themselves to use gestures, movements, voice, and tone in broadcasting activities. Thus, YouTube is really beneficial for them to speak English gradually. On the other hand, other students tend to have less motivation to create an innovative YouTube of broadcasting project since it takes time. It surely seems to be one of the barriers hindering them to learn English especially in speaking English. In other words, it can be deduced that students who lacked proficiency in speaking and writing English will have the big barriers to participation in the workforce [20].

\section{CONCLUSION}

To sum up, this paper mainly focuses on the perception of undergraduate students in Islamic Broadcasting Communication Department of the State Islamic Institute of Kudus 
related to the use of YouTube as a project-based learning in enhancing the speaking proficiency in broadcasting. The findings show that majority of students have positive attitudes and high percentages of using YouTube in encouraging them to speak English. Moreover, they are merely aware of English as a crucial means for their career improvement in broadcasting. Indeed, the lecturers are kindly suggested to be aware of the proficiency levels of their students by giving important exposures for students to speak English. It should be noticed that this study has explored the perception of the undergraduate students in Islamic Broadcasting Department at State Islamic Institute of Kudus towards the use of YouTube as a project-based learning. It is kindly recommended that future researchers conduct such studies in other fields from various disciplines as well as from different countries. By conducting this study, we would mainly obtain wider insights on how social media particularly YouTube can contribute to English development.

\section{Acknowledgments}

We are grateful to the students of Islamic Broadcasting Communication Department at State Islamic Institute of Kudus with whom we have had the pleasure to do a research. They have provided us guidance and insights about the perceptions of using YouTube as a projectbased learning in encouraging their speaking proficiency in broadcasting.

\section{References}

[1] M. Ibrahim, "Media and Religious Engagement: Shaykh Seebaway Zakaria and Ghanaian Broadcasting Media," ARIA (Annual Rev. Islam Africa), no. 11, pp. 7-12, 2013.

[2] Z. Gan, "Understanding L2 Speaking Problems: Implications for ESL Curriculum Development in a Teacher Training Institution in Hong Kong," Aust. J. Teach. Educ., vol. 37, no. 1, pp. 43-59, 2012.

[3] P. C. Talley and T. Hui-ling, "Implicit and Explicit Teaching of English Speaking in the EFL Classroom,” Int. J. Humanit. Soc. Sci., vol. 4, no. 6, pp. 38-46, 2014.

[4] P. Bunus, "The Social Network Classroom," Technol. Enhanc. Learn. Qual. Teach. Educ. reform, vol. 73, pp. 517-524, 2010.

[5] N. A. Buzzetto-more, "An Examination of Undergraduate Student' s Perceptions and Predilections of the Use of YouTube in the Teaching and Learning Process," Interdiscip. J. E-Learning Learn. Objects, vol. 10, pp. 17-32, 2014.

[6] C. Snelson, "YouTube across the Disciplines: A Review of the Literature," MERLOT J. Online Learn. Teach., vol. 7, no. 1, pp. 159-169, 2011.

[7] J. M. Terantino, "Youtube for Foreign Languages : You Have to See This Video," Lang. Learn. Technol., vol. 15, no. 1, pp. 10-16, 2011.

[8] M. Mohamad, I. S. Ismail, N. Wahab, and S. Mamat, "Medical Students' Challenges and Strategies in Producing Web TV Programs on YouTube," Creat. Educ., vol. 7, pp. 604$618,2016$.

[9] S. C. Burke and S. L. Snyder, "YouTube : An Innovative Learning Resource for College Health Education Courses An Overview of YouTube Using YouTube in Higher Education," Int. Electron. J. Health Educ., vol. 11, pp. 39-46, 2008.

[10] W. Prastiyo, A. Djohar, and Purnawan, "Development of Youtube Integrated Google Classroom Based E-Learning Media for The Light-Weight Vehicle Engineering Vocational High School," J. Pendidik. Vokasi, vol. 8, no. 1, pp. 53-66, 2018. 
[11] B. K. B. Fleck, L. M. Beckman, J. L. Sterns, and H. D. Hussey, "YouTube in the Classroom: Helpful Tips and Student Perceptions," J. Eff. Teach., vol. 14, no. 3, pp. 2137, 2014.

[12] P. Duffy, "Engaging the YouTube Google-Eyed Generation: Strategies for Using Web 2 . 0 in Teaching and Learning," Electron. J. e-Learning, vol. 6, no. 2, pp. 119-130, 2008.

[13] A. Khalid and K. Muhammad, "The Use of YouTube in Teaching English Literature The Case of Al-Majma ' ah Community College , Al-Majma ' ah University ( Case Study)," Int. J. Linguist., vol. 4, no. 4, pp. 525-551, 2012.

[14] L. R. Gay, G. E. Mills, and P. W. Airasian, Educational Research Competencies for Analysis and Applications Tenth Editions. Boston: Pearson Prentice Hall, 2012.

[15] G. M. Nalliveettil and T. H. K. Alenazi, "The Impact of Mobile Phones on English Language Learning: Perceptions of EFL Undergraduates," J. Lang. Teach. Res., vol. 7, no. 2, pp. 264-272, 2016.

[16] C. Greenhow and B. Robelia, "Informal learning and identity formation in online social networks," Learn. Media Technol., vol. 34, no. 2, pp. 119-140, 2009.

[17] D. Dewitt, N. Alias, S. Siraj, M. Y. Yaakub, J. Ayob, and R. Ishak, "The potential of Youtube for teaching and learning in the performing arts," Procedia - Soc. Behav. Sci., vol. 103, pp. 1118-1126, 2013.

[18] M. J. Riasati, "Willingness to speak English among foreign language learners : A causal model," Cogent Educ., vol. 7, no. 1, pp. 1-17, 2018.

[19] C. Becker and J. Roos, "An approach to creative speaking activities in the young learners ' classroom An approach to creative speaking activities in the young learners ' classroom," Educ. Inq., vol. 7, no. 1, pp. 9-26, 2016.

[20] R. T. Pithers and R. Lim, "A non-english-speaking background in adult vocational education : breaking through the barriers A Non-English-speaking Background in Adult Vocational Education : breaking through the barriers," J. Vocat. Educ. Train., vol. 49, no. 4, pp. 531-544, 1997. 